\title{
Is There Feminism in Saudi Arabia?
}

\author{
Jacquelyn Hoza \\ Center for Gender, Sexualities, and Women's Studies Research, University of Florida
}

Faculty mentor: Sarra Tlili, Department of Languages, Literatures, and Cultures

\begin{abstract}
The use of the word feminism might be problematic in trying to describe women's movement in Saudi Arabia because of historical and social factors associated with the feminist movement. Feminism is a movement that developed out of Western context and discourse, therefore it might not properly describe what is taking place in Saudi Arabia. A comparison between women's movements in Saudi Arabia and the Western feminist movement reveals important differences, such as the discourse and modes of activism surrounding equality. The aim of this research is thus to challenge the view that Saudi women have no agency and to explore the ways they seek to shape their society and challenge oppressive systems from within their own culture and worldview. This research will discuss why feminist theory may not be the ideal, and certainly not the only system that can address oppressive systems in non-Western societies, including Saudi Arabia. Additionally, this research will describe and analyze the ways in which Saudi women are working towards defining their own views of equity and creating women's movement within their society.
\end{abstract}

\section{Introduction}

A 1990 New York Times article captures aspects of the cultural shock experienced by Saudi and American women when their paths crossed during the Gulf War. "Being here makes me glad to be an American," said a female army major cited in the article, but a Saudi woman, also cited in the article, expressed the same thankfulness for "not being an American." Although this comparison creates the impression of balanced discourse, as one proceeds, Saudi women emerge as voiceless and submissive. "In Saudi society," the author wrote, "women appear to be prohibited from having authority over men, except in rare cases among physicians, for example, or within the private confines of some homes." The author also noted that, "There is no dating or dancing here," and complained that, "Premarital sex remains the object of enduring family shame and social censure." All is not bad, however. The author quoted a Saudi doctor who does not cover her face as saying: "We are changing faster than many people think." ${ }^{1}$ The article's overall theme portrayed Saudi women as deprived of many opportunities, silent, and submissive, and their only way of changing their fate is by conforming to a Western model. 
This New York Times article is part of a body of literature that not only portrays Saudi women as having no agency, but that their only way of being empowered is by emulating the Western model and adopting the Western feminist agenda. Despite its claims to universality, however, feminism is a Western phenomenon and is rooted in Western culture. As such, it may appeal to some, but certainly not to all Saudi women. The aim of this paper is to challenge the view that Saudi women have no agency, and to explore the ways they seek to shape their society and challenge oppressive systems from within their own culture and worldview. To this end, I will first argue that feminist theory may not be the ideal, and certainly not the only system that can address oppressive systems in non-Western societies. Second, I will describe and analyze the ways in which Saudi women are defining their own views of equity and creating an impact on their society.

\section{Feminism}

To understand the backdrop of western depictions of Saudi women, it is important to first outline the history of feminism. The roots of this movement, as June Hannam explains, go back to the mid-eighteenth century when the ideas of the Enlightenment and French Revolution inspired educated white women to question their roles and status in Western societies. ${ }^{2}$ These women wanted to be granted the same rights and privileges as white males and to participate in their respective nations as active citizens. At the time they were able to attend salons and discussion circles where they could engage in thought provoking discussions, but ultimately they remained blocked out of the larger movements taking place in their societies. It should be noted, however, that although these social institutions did not produce immediate concrete changes in women's roles and status, they still constituted a formal space where educated females applied new theories on justice and equality to their own conditions and contemplated a different future. Women also aligned themselves with movements that focused on similar universal justice and equality issues, such as the anti-slavery movement in the West.

These alignments notwithstanding, a crucial feature of feminism consists of its placement of gender at the center of its quest for equality while often neglecting ethnic, racial, religious, cultural and socio-economic factors. This is due to the movement's rootedness in the West, where gender-based discrimination was perceived as the main issue. The elevation of gender over other factors, however, has proved problematic to non-Western women, who face various levels of discrimination and who cannot separate a single factor of their identity as their primary 
disadvantage. Feminism reacts to patriarchy on the level of gender but fails to react to it when other factors of privilege are involved. Hannam writes, "the concerns of women in other parts of the world - for clean water, decent food and access to health care — are then either marginalized or seen as somehow 'less feminist.",3

Many non-Western thinkers took notice of these limitations and sought to create new spaces outside traditional feminism to combat inequalities. One strategy consists of the creation of new versions, such as intersectional feminism, postcolonial feminism, Islamic feminism and womanism. These schools of thought strive to nuance feminist theories and to marry these theories with various aspects of life, such as religion and culture. The emergence of new feminist theories shows how women are reacting to the limits of traditional feminism by creating more inclusive movements. Womanism, a woman's movement that was developed by black women who felt voiceless within traditional feminist circles, has advocated for this by digging into black history. "Naming ourselves meaningfully as we have always done in our cultures historicizes our circumstances and focalizes politics", said the Nigerian writer, Chikwenye Okonjo Ogunyemi. Dorothy Tsuruta commented on this, saying, "Womanism of various kinds invariably upholds the value of self-determination, which includes practices of self-defining, self-naming and selfreliance. ${ }^{\prime 4} \mathrm{New}$ feminist theories and publications have exemplified what womanism has strived for: namely, the creation of spaces to discuss compound factors and women's lived realities outside of the predominately white Western world. Lila Abu-Lughod has similarly highlighted the liberating function of the veil in Islamic societies. Many Muslim women experience this garment as "portable seclusion" which provides them with agency to move about in public spaces while maintaining their respectability and protection. She further points out that in order to understand veiling, Westerners must move past seeing differences as hinderances in justice and accept that different histories and circumstances can manifest as differently structured desires for justice for women, but this does not make justice in this context any less valuable or viable. $^{5}$

Islamic feminism, a relatively new version of the wider movement, has been a direct reaction to the Western model. When the Western feminist movement diffused into Muslim countries many Muslims grappled with its colonial and secular undertones. At the time, Muslim countries were either trying to gain independence or distance themselves from their former colonial rulers of which feminism often served as a reminder. This colonial connotation was 
further compounded by the secular inclination of the feminist movement, which was unpalatable to many Muslims.

Despite these tensions, feminism did develop in Muslim countries but did so in two separate modes of thought. One type is secular feminism, which is headed by upper class Muslim women who often have other links to Europe. The second is Islamic feminism, which is "a feminist discourse and practice articulated within an Islamic paradigm." The phrase "Islamic feminism" was not coined until the 1990s, but women were actively working to combine feminist practices with Islamic teachings from the beginning. It should also be noted that although secular and Islamic feminisms appear to be in tension, Badran points out that "the terms religious and secular are porous rather than rigid categories." ${ }^{, 7}$ Women do not fall into entirely one category or the other.

Muslim women have turned to Islamic feminism because it "fills a niche that Western, individualistic, and secular-based feminism could not reach in traditional, majority Muslim societies." ${ }^{8}$ In contrast with Western feminism with its colonial and secular overtones, the Islamic version gains legitimacy from religious teachings and allows women to work within their own culture and religion to address inequalities. Legitimate authority and cultural compatibility are important due to the centrality of religion in everyday life in Muslim countries. One woman describeed this as "life is religion, religion is life."

Although Islamic feminism continues to grow, many Muslim women still find the phrase problematic, again, due to its colonial and secular overtones. Ziba Mir- Hosseini has also found that many who use the title of Islamic feminism do not often share the same ideals of justice and equality, or agree on the means to attain them. This further complicates Islamic feminist movements because there is no distinct course of action or set of principles to propel their agenda forward. ${ }^{10}$ Accordingly, many continue to look for a term or a phrase with which they can identify; something that can describe equality in terms compatible with their religious beliefs without, nonetheless, including the term "feminism." Despite its universality, the term can be limiting to many women, including in Saudi Arabia. Saudi writer Nura al-Saad is strictly against Western terms such a feminism and universal women's rights due to the West's need to define freedom, while, in her view, "Islam has freed women before the West comes with it's conventions." ${ }^{.11}$ This sentiment is reflected by other Saudi women writers to a lesser extent, but 
nonetheless shows how Saudi women are proud of their Saudi and Islamic heritages and want their movements toward equity to reflect that. ${ }^{12}$

\section{Saudi Arabia and Saudi Arabian Women}

According to the Statistical Yearbook of 2016, issued by the General Authority for Statistics in the Saudi Kingdom, the Saudi population consists of nearly thirty-two million people, of whom Saudis proper (i.e. those who hold Saudi citizenship) are about twenty million. ${ }^{13}$ Formally, Saudi Arabia abides by Islamic Law, Sharia, supplemented by secular codes. Islam is the official religion and non-Muslims may not obtain citizenship. Saudi Arabia observes sex segregation and enforces this rule through the body of religious police known as muțwwa: This has resulted in separate areas for families, women and single men in both public and private sectors. This allows "all activities in public ...to be conducted in a manner that does not lead to any intermingling of unrelated men and women." 14 Separate areas can be seen in restaurants, malls, conferences, festivals, and even family parties or functions. When in public spaces, women must wear the abaya, hijab and niqab, but they may remove these garments in some women-only spaces.

The interest of the Western public, specifically in America, in Saudi women was mainly triggered by the 1991 Gulf War. As Saddam Hussein approached the Saudi border, the United States sent troops to Saudi Arabia to stop another invasion by Iraq. This was the formal start of the Gulf War which witnessed the largest deployments of female soldiers in American history. The experiences of military women were heavily documented in Western media. These women reportedly pointed out the different restrictions they faced compared to their male counterparts, like having to cover their arms and legs. American servicewomen could only drive military vehicles while on duty, but at no other times. Many of them also reported their conflicts with Saudi police, which they believed exemplified Saudi patriarchy. Feminist advocates and academics accused the United States officials of hypocrisy, blaming them for helping a country that violated basic human rights. American feminists lobbied to change these foreign policies and succeeded when the Clinton administration refused to recognize the legitimacy of the Taliban based on the latter's supposed violation of women's human rights. In these debates, Saudi and other Muslim women consistently came across as lacking agency and in need of the help of Western feminists to achieve equality. ${ }^{15}$ 


\section{Progress Towards Equity}

Contrary to these assumptions, women's movement in Saudi Arabia takes multiple forms and has made strides towards equity, especially at the social (as opposed to the legal) level. The phrase "women's movement" should be understood in a loose sense, as it does not necessarily refer to coordinated efforts. Indeed, protests and organized political movements are strictly outlawed in the Kingdom. ${ }^{16}$ Women who engage in various modes of empowerment may not present these modes as movements or as conscious effort to change society; nevertheless, regardless of how one thinks of these efforts, they are leading to concrete results, as recently illustrated in the lifting of the driving ban on women.

\section{Online Advocacy}

Digital technology has provided Saudi women with unprecedented opportunities for the exchange of ideas. Thanks to its non-gendered nature, the internet, said Hala Gutal and Magdalena Karolak, "creates a space where women have an equal access and they are able to contribute to the public sphere in ways that are not possible outside of the virtual world." ${ }^{17}$ As a result, the activity of Saudi female bloggers, who according to the same authors contribute 50\% of all Saudi blogs, "is innovative in the sense that it enables full participation of women in this new public sphere and it enhances their ability to acquire a form of influence in society." 18 Women are thus becoming agents of change in the Kingdom. "Blogs such as Saudi Eve, Saudiyat, Saudiwoman's weblog and women2drive campaign are examples of women bloggers trying to bring about a change of their status in Saudi society." 19

Some have argued that increased globalization is leading Saudi women to "become less likely to accept traditional models of political and gender regimes. ${ }^{20}$ Although this must be true of many women, numerous online discussions reveal also that religion and traditional culture continue to be a source of empowerment for many others. Annamaria Szilagyi affirmed that Saudi women continue to try to "fulfil the cultural expectations of the conservative Saudi Arabian society" while also being "eager to take an active role in their education and career

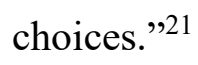

\section{Work and Entrepreneurship}

Many women find empowerment through conventional channels, such as employment in the public and private sectors. The number of women in the workforce is on the rise in the Saudi Kingdom, rising from $5.4 \%$ in 1992 to $14.4 \%$ as of $2007,{ }^{22}$ with most being employed in the 
field of education and in government offices. A smaller percentage of women also work in the private sector, especially in the areas of finance, business services, construction, manufacturing and retail. Many female entrepreneurs affirm that they find strong support from their families. ${ }^{23}$ This shows that Saudi women continue to work within traditional frames to create new types of empowerment. These women still face many challenges, especially ones pertaining to government regulations and cultural barriers. For example, some entrepreneurs report that they have difficulty finding local employees and some cite the necessity to find a male business guardian as a major challenge, but these barriers appear to be slowly fading away. One study found that, "as age was found to be the most predictor of males' attitudes towards working women, the traditional attitudes may gradually become more egalitarian as the new generations based on liberal gender socialization replace the old one." 24 This could have great ramifications for Saudi women in the workforce and it appears that Saudi women will continue to increase their presence in the workforce as they find empowerment and opportunities through it.

\section{Group Activism}

May al-Dabbagh wrote that the "general landscape for independent activism is extremely restricted and regulated" in the Saudi Kingdom, nevertheless, she described a variety of ways in which Saudi women are seeking to shape their society. ${ }^{25}$ Al-Dabbagh categorized female political involvement into four broad orientations; namely, liberal, rights-based, Islamist feminist and conservative. Obviously, these groups "have varying perspectives on how they define and pursue social change agendas" but having "social change agendas" is their common denominator. ${ }^{26}$ Liberal groups want "a larger role for women in public life", al-Dabbagh wrote, whereas the rights-based group are working to improve the rights of prisoners. Islamist feminists “offer revisionist readings of Islamic texts and seek to transform Islamic teachings on women's issues from within." Finally, conservative groups, "can be critical of the United Nations and

other bodies of transnational governance that impinge on state sovereignty." 27 These women may thus have different ideas about the ideal society they seek to build, but all of them seem to take profound interest in social issues and to work hard to influence them.

Another shared feature between these groups is their avoidance of the "feminist" label. Al-Dabbagh said, "Most groups do not operate with a feminist or exclusively feminist agenda... The term feminist (nasawiyya) is not widely used, nor is it agreed on by women working on women's issues." 28 Many Saudi women prefer to use the term womanist or female (nisā 'iyya), 
which reflects similar sentiments in the womanism movement in the United States. This avoidance suggests that Saudi women feel little affinity with Western feminism.

\section{Everyday Transgression}

Many young Saudi women express their agency by breaking dress code rules, while still observing and respecting religious laws. For example, "Young Saudi women are veiled, but the veil, supposedly serving to hide the body according to official religious texts, is diverted: the shoulder abaya, fluid, embroidered, sometimes decorated with sequins, becomes a seductive fashion accessory." 29 While these transgressions seem simple, they create widespread change over time. Young women note at their universities that, "their repeated occurrence in public, in the faces of the authorities, engenders a disordering of the latter's rule." 30 This type of activism is subtle, but nevertheless has allowed Saudi women to exercise their agency by combining modern fashion and traditional religious standards. They are creating new spaces of action for women through unofficial channels, which further shows the agency of women acting within Saudi's societal constraints. Although these may appear as mere individual approaches, they do have a collective nature to them. As more women take individual approaches towards empowerment, it allows the transgression efforts to be more successful and common place, so individuals are not harshly punished for committing them.

\section{The Problematic Nature of Describing Saudi Women's Movement as Feminism}

Cumulative evidence shows that there are recurrent patterns, something that can lead to macro level conclusions. This approach is heavily influenced by C. Wright Mills' concept of Sociological Imagination as "the vivid awareness of the relationship between experience and the wider society." "31 Since Saudi Arabia bans many movements and protests, many women's movements are often individual acts of transgression, empowerment, or other types of individual agency that becomes interconnected in society, often unintentionally. While these movements do not always result in legal changes, they do result in social changes, therefore gradually transforming the status and roles of women. More importantly, this type of activism does not reject Saudi society, culture or laws, but rather embraces them in new ways. This can be seen in the way women conceptualize their own acts of empowerment. Even if they do not articulate their ideas in a language that makes use of Western concepts or terminology, a careful observer can still see interesting parallels between Western feminism and women's movements in Saudi Arabia. Saudi Women are now undertaking their own reading of religious texts and putting 
"together their own classifications of religious precepts, distinguishing between those they esteem necessary and those they esteem optional."32 They do not question Islam nor Saudi culture, but they do question readings thereof. There are many Saudi women who are proud of their Muslim roots, traditional family culture. One Saudi woman said, we "need to keep our identity... I'm a Muslim woman and a Saudi woman even if I'm wearing jeans." 33 Many Western feminists may fail to appreciate this position as they tend to link religion and traditional family values to patriarchy. Many also may consider lack of political activism as problematic, as it would be suspected of fragmenting women's movements and leading to little tangible progress. This does not seem to be the case in Saudi Arabia. Non-political movements often create the most significant change, as seen through acts of transgression through styles of dress.

While striving to gain more rights, Saudi women are typically careful to distance themselves from Western feminism. This stance has a parallel in the United States among women who prefer to use the word "womanism." Saudi women seem to distrust the feminist discourse as they feel that it portrays them as voiceless and submissive. Moreover, the Western feminist agenda and Saudi women's goals for empowerment do not align often. For example, many Western feminists would perceive women-only spaces as exclusionary. In Saudi Arabia, many women prefer women-only spaces as they empower them in a culture that values the differences between men and women. The differences in goals between mainstream Western feminists and Saudi women are due to cultural and societal differences, which mainstream Western feminism has not taken the time to understand or incorporate into the women's rights agenda.

\section{Conclusion}

Saudi women's methods of improving their conditions diverges significantly from Western models, but this does not mean it is any less effective or important. Saudi women's approach is compatible with their cultural values while still challenging gender-related and other inequalities. As new interpretations of feminism and more nuanced ways of understanding the notion of equity evolve, it is important to revisit the roots of feminism to understand why the definition of women's rights must be expanded as well. At the core of feminism, women are on a universal search for justice to create equitable outcomes for all. Saudi women are part of this search but might have different conceptions of what qualifies as equitable. Saudi women's efforts are part of a universal struggle to build more just societies. Their "movement" may not be a movement in the strict sense 
of the word and their methods may diverge significantly from Western models, but this should not disqualify their efforts as meaningless or less worthy.

\section{References}

Abu-Lughod, Lila. "Lila Abu-Lughod on Attitudes Toward Muslim Women in the West." Interview by Nereem Shaikh. Asia Society, March 20, 2002. https://asiasociety.org/lila-abu-lughod-attitudestoward-muslim-women-west.

Al-Dabbagh, May. "Saudi Arabian Women and Group Activism." Journal of Middle East Women's Studies 11, no. 2 (2015): 235-237.

Al Fassi, Hatoo Ajwad. "Saudi Women and Islamic Discourse, Selected Examples of Saudi Feminisms," Journal of the Women of the Middle East and the Islamic World 14 (2016): 187-206.

Al-Saad, Nura. "Gender, the Concept and Objective," Al-Riyadh Newspaper, February 7, 2015. http://www.alriyadh.com/2004/05/16/article15331.html.

Badran, Margot. Feminism in Islam: Secular and Religious Convergences. London: OneWorld Publications, 2013.

Crossman, Ashley. "Definition of Sociological Imagination and Overview of the Book." Social Sciences, Thought Co., last modified July 28, 2017. https://www.thoughtco.com/sociological-imagination$\underline{3026756 .}$.

Elamin, Abdallah M. and Katlin Omair. "Males' attitudes towards working females in Saudi Arabia." Personnel Review 39.6 (2010): 746 - 766.

Gonzalez, Alessandra L. Islamic Feminism in Kuwait: The Politics and Paradoxes. New York: Palgrave Macmillan, 2013.

Guta, Hala and Magdalena Karolak. "Veiling and Blogging: Social Media as Sites of Identity Negotiation and Expression among Saudi Women." Journal of International Women's Studies 16, no. 2 (2015): 115-127.

Hannam, June. Feminism. London: Routledge, 2014.

Kingdom of Saudi Arabia General Authority for Statistics. "Statistical Yearbook of 2016- Chapter 02 Population.” Accessed January 21, 2018. https://www.stats.gov.sa/en/866-0.

Le Renard, Amelie. A Society of Young Women: Opportunities of Place, Power, and Reform in Saudi Arabia. Stanford: Stanford University Press, 2014.

Lemoyne, James. "CONFRONTATION IN THE GULF; Army Women and the Saudis: The Encounter Shocks Both." The New York Times, September 25, 1990.

https:/www.nytimes.com/1990/09/25/world/confrontation-in-thegulf-army-women-and-thesaudis-the-encounter-shocks-both.html?pagewanted=all

Mir-Hosseini, Ziba. “Beyond 'Islam’ Vs ‘Feminism'.” IDS Bulletin 42.1 (2011): 67-77. 
Quamar, Md. Muddassir. "Sociology of the Veil in Saudi Arabia: Dress Code, Individual Choices, and Questions on Women's Empowerment.” Digest of Middle East Studies 25.2 (2016): 315-337.

Sadat, Mirdamad Yosefy. “Globalization and International Women's Movement." Journal of Current Research in Science 3.6 (2015): 39-44.

Shannon, Kelly J. "'I'm Glad I'm Not a Saudi Women': The First Gulf War and US Encounters with Saudi Gender Relations." Cambridge Review of International Affairs 27.3 (2014): 553-573.

Szilagyi, Annamaria. "'I Am Different From Other Women In the World' The Experiences of Saudi Arabian Women Studying Online in International Master Programmes." European Journal of Open, Distance and e-Learning 18.1 (2015): 85-98.

Tsuruta, Dorothy Randall."The Womanish Roots of Womanism: A Culturally-Derived and AfricanCentered Ideal (Concept).” The Western Journal of Black Studies 36.1 (2012): 3-10.

Welsh, Dianne H.B., Esra Memili, Eugene Kaciak, Aliyah Al Sadoon. "Saudi women entrepreneurs: A growing economic segment.” Journal of Business Research 67.5 (2014): 758-762.

\section{Endnotes}

${ }^{1}$ James Lemoyne, "Confrontation in the Gulf, Army Women and the Saudis: The Encounter Shocks Both," The New York Times, September 25, 1990,

https://www.nytimes.com/1990/09/25/world/confrontation-in-the-gulf-army-women-and-the-saudis-theencounter-shocks-both.html?pagewanted=all. Accessed on April 2, 2018.

${ }^{2}$ June Hannam, Feminism (London: Routledge, 2014), 11-18

${ }^{3}$ Hannam, Feminism, 6.

${ }^{4}$ Dorothy Randall Tsuruta. "The Womanish Roots of Womanism: A Culturally-Derived and AfricanCentered Ideal (Concept)," The Western Journal of Black Studies 36, No. 1 (2012),5.

${ }^{5}$ Lila Abu-Lughod, "Lila Abu-Lughod on Attitudes Toward Muslim Women in the West," interview by Nereem Shaikh, Asia Society, March 20, 2002, https://asiasociety.org/lila-abu-lughod-attitudes-towardmuslim-women-west.

${ }^{6}$ Margot Badran, Feminism in Islam: Secular and Religious Convergences (London: OneWorld Publications, 2013), 234.

${ }^{7}$ Ibid., 230.

${ }^{8}$ Alessandra L. Gonzalez, Islamic Feminism in Kuwait: The Politics and Paradoxes (New York: Palgrave Macmillan, 2013), 24.

${ }^{9}$ Ibid., 29.

${ }^{10}$ Ziba Mir-Hosseini, “Beyond 'Islam' Vs 'Feminism',” IDS Bulletin 42, No. 1 (2011), 71.

11“'Statistical Yearbook of 2016- Chapter 02 Population,"General Authority for Statistics, Kingdom of Saudi Arabia accessed January 21, 2018. https://www.stats.gov.sa/en/866-0.

${ }^{12}$ Nura Al-Saad, "Gender, the Concept and Objective," Al-Riyadh Newspaper, February 7, 2015, http://www.alriyadh

.com/2004/05/16/article15331.html. Accessed on August 26, 2018. 
${ }^{13}$ Hatoo Ajwad A1 Fassi, "Saudi Women and Islamic Discourse, Selected Examples of Saudi Feminisms," Journal of the Women of the Middle East and the Islamic World 14 (2016): 202.

${ }^{14}$ Kelly J Shannon, “'I'm Glad I'm Not a Saudi Women': The First Gulf War and US Encounters with Saudi Gender Relations," Cambridge Review of International Affairs 27.3 (2014): 553-555.

${ }^{15}$ Md. Muddassir Quamar, "Sociology of the Veil in Saudi Arabia: Dress Code, Individual Choices, and Questions on Women's Empowerment," Digest of Middle East Studies 25.2 (2016): 318, https://doi.org/10.1111/dome.12085

${ }^{16}$ Amelie Le Renard, A Society of Young Women: Opportunities of Place, Power, and Reform in Saudi Arabia (Stanford: Stanford University Press, 2014), 115.

${ }^{17}$ Hala Guta1 and Magdalena Karolak, "Veiling and Blogging: Social Media as Sites of Identity Negotiation and Expression among Saudi Women” Journal of International Women's Studies 16.2 (2015), 117.

${ }^{18}$ Ibid., 116.

${ }^{19}$ Ibid., 117.

${ }^{20}$ Mirdamad Yosefy Sadat, “Globalization and International Women's Movement," Journal of Current Research in Science 3, no.6 (2015): 41.

${ }^{21}$ Annamaria Szilagyi, "II am different from Other Women in the World' The Experiences of Saudi Arabian Women Studying Online in International Master Programmes," European Journal of Open, Distance and e-Learning 18.1 (2015), 96.

${ }^{22}$ Dianne H.B. Welsh et al. "Saudi women entrepreneurs: A growing economic segment" Journal of Business Research 67.5 (2014), 758.

${ }^{23}$ Welsh et al. "Saudi Women Entrepreneurs," 760.

${ }^{24}$ Abdallah M. Elamin and Katlin Omair, "Males' attitudes towards working females in Saudi Arabia," Personnel Review 39.6 (2010), 762.

${ }^{25}$ May Al-Dabbagh, "Saudi Arabian Women and Group Activism," Journal of Middle East Women's Studies 11. 2 (2015), 235.

${ }^{26}$ Ibid., 235.

${ }^{27}$ Ibid., 236.

${ }^{28}$ Ibid., 235.

${ }^{29}$ Le Renard, A Society of Young Women, 110.

${ }^{30}$ Ibid., 113-114.

${ }^{31}$ Ashley Crossman, "Definition of Sociological Imagination and Overview of the Book," Social Sciences, Thought Co., last modified July 28, 2017, https://www.thoughtco.com/sociological-imagination3026756.

\footnotetext{
${ }^{32}$ Le Renard, A Society of Young Women, 121.

${ }^{33}$ Ibid., 122.
} 